\title{
An examination of firm size on intra-family business succession
}

\section{Archie Lockamy III}

\author{
Brock School of Business, \\ Samford University, \\ Birmingham, AL, USA \\ Fax: (205) 726-2464 \\ Email: aalockam@samford.edu
}

\begin{abstract}
This study examines the effect of firm size on intra-family business succession. The study extends the work of Lockamy et al. (2016) which identified key determinants which inhibit intra-family business succession. Their study indicated that there are four key constructs comprised of 23 variables which have the most influence on deterring intra-family business successions. These variables were used to construct Bayesian networks to determine if firm size affects the probability that intra-family business succession does not occur within a firm. The study results indicate that there is a higher probability that intra-family business succession does not take place in a smaller firm, as measured by its number of employees. The results also suggest managerial actions that can be taken to improve the probability of intra-family business succession in smaller firms.
\end{abstract}

Keywords: family business; conflict avoidance; succession planning; business succession; firm size; Bayesian networks.

Reference to this paper should be made as follows: Lockamy III, A. (2020) 'An examination of firm size on intra-family business succession', Int. J. Family Business and Regional Development, Vol. 1, No. 1, pp.46-61.

Biographical notes: Archie Lockamy III is the Margaret Gage Bush Professor of Business and Professor of Operations Management at Samford University. Prior to his academic career, he held various engineering and managerial positions with DuPont, Procter and Gamble, and TRW. He has published research articles in numerous academic journals and co-authored the book Reengineering Performance Measurement: How to Align Systems to Improve Processes, Products and Profits. He served on the 1997, 1998, 1999, 2000, 2001, and 2002 Board of Examiners for the Malcolm Baldrige National Quality Award via appointment by the United States Department of Commerce. He also served as Vice President of the Board of Directors of the American Production and Inventory Control Society (APICS) Educational and Research Foundation. $\mathrm{He}$ is recognised as a Certified Fellow in Production and Inventory Management (CFPIM) by APICS and is certified as an Academic Jonah by the Avraham Y. Goldratt Institute. 


\section{Introduction}

Management succession has been identified as one of the most critical issues faced by family business leaders (Chua et al., 2003). Moreover, this issue has been cited as the most frequently researched topic in the family business literature (Handler, 1992; Montemerlo, 2000; Brockhaus, 2004; Ward, 2004). An examination of the literature reveals that only a limited number of family businesses are successfully transitioned to the second generation, and many of these transitions fail soon after the second generation begins to manage the business (Sonnenfeld, 1988; Handler, 1990, 1992; Morris et al., 1997; Davis and Harveston, 1998; Ward, 1997, 2004). Predictably, family business consultants are frequently utilised to assist in issues relating to management succession (Upton et al., 1993).

While numerous articles have been written on family business succession, a review of the literature reveals that there is a lack of empirical research demonstrating the key determinants that prevent the transfer of managerial control from one family member to another. De Massis et al. (2008) developed a model containing factors that prevent intra-family management succession based on a comprehensive review and analysis of the family business literature. However, the model is theoretical in nature and lacks empirical support. Lockamy et al. (2016) extended the work of De Massis et al. (2008) and other family business researchers by identifying key determinants which inhibit intrafamily business succession via empirical analysis. The study explored the effects these determinants have on preventing intra-family business succession, along with the probability that intra-family business succession does not take place based upon the effects of the identified determinants. Factor analysis was used to determine the most influential factors, and Bayesian networks were constructed to determine the probability that intra-family business succession does not occur based upon these factors. The study results indicated that there are four key factors comprised of 23 variables which have the most influence on deterring intra-family business successions. This research extends the work of Lockamy et al. (2016) by examining the effect of firm size on intra-family business succession using the four key factors outlined in their study. The research results indicate that there is a higher probability that intra-family business succession does not take place in a smaller firm, as measured by its number of employees. The results also suggest managerial actions that can be taken to improve the probability of intra-family business succession in smaller firms.

The article is organised as follows. The first section of the article provided the motivation for and focuses of the study. A review of the literature is provided in Section 2. Section 3 contains an overview of the research methodology used in this study. Section 4 contains the results of the study. Proposed managerial actions based upon the results of the study are provided in Section 5. Conclusions are offered in Section 6. Finally, study limitations and directions for future research are offered in Sections 7 and 8 respectively.

\section{Literature review}

An analysis of the family business research literature indicates that scholars in this area have primarily employed p-value null hypothesis significance testing (pNHST) methods 
when conducting empirical studies (Dean et al., 2007). However, some organisational researchers have suggested that methods based on other approaches might help advance the field by incorporating different assumptions and methods into empirical analyses. For example, pNHST-based studies often employ group means as part of their calculations, which may statistically neutralise significant differences among individuals or organisations that scholars seek to explain (e.g., Hansen et al., 2004). In addition, researchers cannot employ pNHST methods to compare support for one theoretical model versus another because p-values only provide evidence to support or reject the null hypothesis (Andraszewicz et al., 2015). Thus, other methods that overcome these potential limitations may be needed to study critical issues relating to family businesses.

Bayesian analysis represents one such set of methods, and scholars in other business fields have increasingly employed these methods to study issues such as decision making. For instance, Allenby et al. (2004) found over 50 articles published in top marketing journal that examined Bayesian methods issues during the 1990s. Given its many advantages, Bayesian methods provide a critical methodological tool for organisational scholars and family business researchers (Kruschke et al., 2012). Moreover, Bayesian analysis enables scholars to assess how decision makers update their estimated probabilities of potential outcomes as new data become available, making it a useful method for studying decision making throughout the life-cycle process of family businesses. Finally, Bayesian analysis employs previous results as an input and faces fewer restrictions on sample size than pNHST-based methods (Zyphur and Oswald, 2013). To date, Bayesian methods have seen only limited use in family business research. Extant research has mostly been conceptual or employed simulated data. However, this limited research has shown the value of employing these methods in studying family business processes and topics (Block et al., 2014).

The family business research literature cites a myriad of circumstances which prevent intra-family succession. This literature can be segmented into the following categories: process factors, financial factors, individual factors, context factors, relationship factors, and governance factors. The following is a review of the literature in each of the above-mentioned categories.

\subsection{Process factors}

Several studies suggest that process factors often inhibit succession from taking place. This category is comprised of factors associated with the succession process that prevents intra-family succession (De Massis et al., 2008). These factors include: a lack of clearly defined roles for the incumbent business leader and potential successors (Lansberg, 1988); poor communication of the succession process with family members and other stakeholders (Dyer, 1986; Ward, 1987); failing to train potential successors (Churchill and Hatten, 1987; Ward, 1987; Morris et al., 1997); a lack of rational and objective criteria for successor selection (Levinson, 1971); and a lack of consistency between criteria used for previous successions within the business (Kim and Mauborgne, 1993). Since process factors directly impact successor preparation, evaluation, and communication with critical stakeholders, they can either worsen or improve the individual or relationship factors that might prevent intra-family succession (De Massis et al., 2008). 


\subsection{Financial factors}

The family business research literature suggests that financial factors could inhibit succession. This category is comprised of factors related to the internal financial resource limitations of the family business, and the opportunity cost of obtaining external financing (De Massis et al., 2008). These factors include the inability to sustain the tax burden related to succession (e.g., inheritance), and the lack of financial resources to hire professional managers to assist under-qualified successors (Parrini, 2000). For example, the tax burden associated with an inheritance of the business could exceed the family's liquid resources, resulting in the prevention of intra-family succession (Parrini, 1998, 2000). Although the selling of shares either privately or publicly to raise funds may be a viable option, the reduction of family ownership in the business would significantly reduce the probability of intra-family succession (De Massis et al., 2008). Finally, if professional managers must be hired to assist under-qualified successors, the business will incur agency costs (Eisenhardt, 1989). These costs may also reduce the likelihood of intra-family succession (De Massis et al., 2008).

\subsection{Individual factors}

Factors related to either the successor or the incumbent (collectively categorised as individual factors) were also cited in the literature as deterrents to intra-family succession. Successor-related factors include the unexpected loss of potential successors (Handler and Kram, 1988), the potential successors' lack of motivation or satisfaction (Chrisman et al., 1998; Sharma and Rao, 2000), and a low ability of the potential successors to manage the family business (Barach et al., 1988; Barach and Gantisky, 1995). Handler and Kram (1988) suggest that if the potential successor dies or becomes ill, intra-family succession is no longer possible if only one potential family successor exists in the business. Additionally, the potential successors' lack of motivation or satisfaction could deter intra-family succession due to the successor refusing the position or not receiving the appointment (De Massis et al., 2008). Moreover, if a potential successor is not capable of managing the business, intra-family succession may not take place due to the successor refusing the position or not receiving the appointment (De Massis et al., 2008). Incumbent-related factors cited in the literature include the unexpected loss of the incumbent business leader (Kelly et al., 2000) and the incumbent's divorce, remarriage, or new children (Dick and Kets de Vries, 1992). Since the incumbent usually plays a significant role in the succession decision, the unexpected loss of the incumbent business leader could prevent intra-family succession (De Massis et al., 2008). De Massis et al. (2008) also note that the loss of the incumbent may occur at a time when the potential successor may not have the ability or motivation to take over the family business.

\subsection{Context factors}

Business ambiguities, referred to in the family business literature as context factors, are identified as key influencers leading to the prevention of intra-family succession. Changes in business performance (Sharma et al., 2001; Molly et al., 2010; Gedajlovic et al., 2012), decreased business scale (Stavrou, 1999) and a loss of key customers or 
suppliers are among the context factors which may impede intra-family succession. For example, an actual or expected decline in business performance may reduce the willingness of the potential successor to take over the family business (De Massis et al., 2008). A study by Stavrou (1999) suggests that a decrease in business size may result in a potential successor leaving the business. Finally, if key customers and suppliers are not willing to establish a personal and trusting business relationship with the potential successor, intra-family succession may not take place if those customers and suppliers are essential to the family firm's existence.

\subsection{Relationship factors}

Personal relationships among family and non-family members can directly influence intra-family succession (Davis, 1983; Lansberg, 1983; Churchill and Hatten, 1987; McCollom, 1988). The literature suggests that poor interpersonal relationships can cause potential conflicts which obstruct intra-family succession (Lansberg, 1983; Kepner, 1983; Rosenblatt et al., 1985). Relationship factors include: lack of commitment to the potential successors by family members (Kets de Vries, 1989) or non-family members (Kets de Vries, 1986); lack of trust in the potential successor by family members (Barach et al., 1988); conflicts among family members (Churchill and Hatten, 1987); and conflicts between potential successors and non-family members (Bruce and Picard, 2006). De Massis et al. (2008) suggest that if family or non-family members are not committed to the potential successor, the individual may not be given an opportunity to demonstrate an ability to lead the family business. Thus, the potential successor may withdraw their candidacy and inhibit intra-family succession. Similarly, a lack of trust in the potential successor by family members can deter intra-family succession (De Massis et al., 2008). Sibling rivalries may prevent the appointment of a successor or discourage family members from applying for the position. Thus, conflicts among family members can also inhibit intra-family succession. Finally, Bruce and Picard (2006) note that conflicts between potential successors and non-family members can be a barrier to intra-family succession due to the potential successor opting to refuse the leadership position to avoid such conflicts.

\subsection{Governance factors}

The family business research literature cites corporate governance factors as impediments to intra-family succession (Combs et al., 2010). These factors include the degree to which the board of directors (BOD) is dominated by family members, and whether the incumbent serves as both the chief executive officer and chairman of the BOD. Additionally, there have been several research studies illustrating the impact of governance factors on the performance and sustainability of family businesses (Basco and Rodríguez, 2009; Fahed-Sreih, 2009; Brenes et al., 2011; Kuan et al., 2011; Berent-Braun and Uhlaner, 2012; Siebels and zu Knyphausen-Aufseß, 2012; Yu et al., 2012; Adendorff and Halkias, 2014). Kuan et al. (2011), Berent-Braun and Uhlaner (2012), and Adendorff and Halkias (2014) revealed that governance played a significant role in the long-term business performance of family businesses. Basco and Rodríguez (2009) found that governance had a direct impact on family business enterprise management. Fahed-Sreih (2009), Brenes et al. (2011), and Siebels and zu Knyphausen-Aufseß (2012) conducted studies which indicated that the appropriate 
family business governance structure is essential to the long-term survivability of the firm. Finally, in a study conducted by Yu et al. (2012), it was revealed that governance played a significant role in the succession outcomes of family businesses. The above-mentioned literature along with other articles was used in this study to provide a basis for identifying key determinants which prevent intra-family business succession. De Massis et al. (2008) developed a theoretical model comprised of factors preventing intra-family succession in family firms. The model contains five constructs (i.e., process factors, individual factors, relationship factors, context factors, and financial factors) represented by 28 variables. The authors purport that these constructs could lead to three exhaustive but not mutually exclusive events that prevent intra-family succession from occurring: first, all potential family successors decline the leadership role of the business; second, the dominant coalition within the business rejects all potential family successors; or finally, the dominant coalition decides against family succession although acceptable and willing potential family successors exits. The next section of the paper provides a description of the research methodology used in the study.

\section{Research methodology}

This study is an extension of the research conducted by Lockamy et al. (2016), and designed to address the following question:

Q1 What is the effect of firm size on intra-family business succession?

Table 1 Factor analysis results

\begin{tabular}{lcccc}
\hline Variable & Individual/relationships & Process & Context & Governance \\
\hline TrFam3 & 0.921 & 0.252 & 0.009 & 0.012 \\
TrFam1 & 0.916 & 0.3 & -0.018 & -0.011 \\
CommFam1 & 0.909 & 0.16 & 0.111 & 0.099 \\
Conf2 & 0.904 & 0.097 & 0.11 & -0.041 \\
DisMot2 & 0.892 & 0.251 & 0.088 & 0.031 \\
TrNonFam1 & 0.867 & 0.323 & -0.075 & -0.023 \\
FamRiv1 & 0.863 & 0.175 & 0.157 & -0.01 \\
DisMot3 & 0.852 & 0.241 & 0.113 & 0.08 \\
CommNon1 & 0.84 & 0.438 & -0.051 & -0.017 \\
TrFam2 & 0.828 & 0.422 & 0.006 & -0.004 \\
TrNonFam7 & 0.809 & 0.157 & 0.311 & -0.062 \\
Skills3 & 0.803 & 0.322 & 0.068 & 0.137 \\
DisMot1 & 0.764 & 0.378 & 0.221 & 0.087 \\
Conf3 & 0.728 & -0.004 & 0.331 & 0.136 \\
Skills5 & 0.727 & 0.322 & 0.154 & 0.201 \\
Loss1 & 0.474 & 0.78 & -0.046 & 0.128 \\
Loss2 & 0.403 & 0.734 & 0.03 & 0.287 \\
Late3 & 0.25 & 0.756 & 0.347 & -0.004 \\
\hline
\end{tabular}


Table 1 Factor analysis results (continued)

\begin{tabular}{lcccc}
\hline Variable & Individual/relationships & Process & Context & Governance \\
\hline IdentCrit1 & 0.182 & 0.728 & 0.243 & 0.037 \\
Perf1 & 0.192 & 0.14 & 0.796 & 0.029 \\
NoObj3 & 0.099 & 0.218 & 0.761 & 0.321 \\
Dual1 & -0.214 & 0.059 & 0.372 & 0.734 \\
BoDFam1 & 0.223 & 0.15 & 0.021 & 0.872 \\
\hline
\end{tabular}

Table 2 Key determinants preventing intra-family succession in family businesses

\begin{tabular}{|c|c|c|}
\hline Variable & Description & Construct \\
\hline BodFam1 & Family-comprised BOD & Governance factor \\
\hline Dual1 & Incumbent is CEO and chairman of the BOD & Governance factor \\
\hline NoObj3 & Informal succession plan & Context factor \\
\hline Perf1 & Financial performance decline & Context factor \\
\hline IdentCrit1 & $\begin{array}{l}\text { Successor will be selected using identical criteria } \\
\text { from previous successions }\end{array}$ & Process factor \\
\hline Late3 & $\begin{array}{c}\text { Successor lacks work experience in the family } \\
\text { business }\end{array}$ & Process factor \\
\hline Loss 1 & Successor lacks relationships with major customers & Process factor \\
\hline Loss 2 & Successor lacks relationships with major suppliers & Process factor \\
\hline Conf2 & $\begin{array}{c}\text { Conflicts between successor and non-family } \\
\text { members }\end{array}$ & Individual/relationship factor \\
\hline Conf3 & Rivalry among the children (potential successors) & Individual/relationship factor \\
\hline CommFam1 & $\begin{array}{l}\text { Family members dissatisfied with successor's } \\
\text { commitment to the business }\end{array}$ & Individual/relationship factor \\
\hline CommNon 1 & $\begin{array}{l}\text { Non-family members dissatisfied with the } \\
\text { successor's commitment to the business }\end{array}$ & Individual/relationship factor \\
\hline DisMot1 & $\begin{array}{l}\text { Incumbent is dissatisfied with the successor's } \\
\text { commitment to the business }\end{array}$ & Individual/relationship factor \\
\hline DisMot2 & Successor is not motivated to run the business & Individual/relationship factor \\
\hline DisMot3 & Successor lacks commitment to the business & Individual/relationship factor \\
\hline FamRiv1 & $\begin{array}{l}\text { Successor has conflicts with family members } \\
\text { (other than the incumbent) }\end{array}$ & Individual/relationship factor \\
\hline Skills3 & $\begin{array}{c}\text { Successor lacks the decision making skills needed } \\
\text { to run the business }\end{array}$ & Individual/relationship factor \\
\hline Skills5 & $\begin{array}{c}\text { Successor lacks the interpersonal skills needed to } \\
\text { run the business }\end{array}$ & Individual/relationship factor \\
\hline TrFam1 & Family members question the successors' integrity & Individual/relationship factor \\
\hline TrFam2 & Family members lack trust in the successor & Individual/relationship factor \\
\hline TrFam3 & $\begin{array}{l}\text { Successor is not seen as a legitimate leader by } \\
\text { family members }\end{array}$ & Individual/relationship factor \\
\hline TrNonFam1 & $\begin{array}{l}\text { Non-family members question the successors' } \\
\text { integrity }\end{array}$ & Individual/relationship factor \\
\hline TrNonFam7 & $\begin{array}{c}\text { Family members do not work well together as a } \\
\text { team }\end{array}$ & Individual/relationship factor \\
\hline
\end{tabular}


The questions used in the survey instrument for the Lockamy et al. (2016) study were based upon the work of De Massis et al. (2008) along with other studies examined during the literature review. The survey instrument used in their study assessed six constructs (i.e., context, individual, relationship, process, governance, and financial factors) represented by 49 variables believed to prevent intra-family succession. The variables used by Lockamy et al. (2016) were derived from factors contained in the De Massis et al. (2008) study, along with information obtained from a comprehensive review of the literature. The researchers conducted factor analysis using principle components on the survey results to establish the key determinants which prevent intra-family succession as suggested by the survey respondents. The results of their analysis are presented in Table 1. A listing of the key determinants found to prevent intra-family succession along with a brief description of their associated variables is provided in Table 2. The four-factor solution contains four constructs consisting of 23 variables that explain $79.8 \%$ of the variance. The results of the Lockamy et al. (2016) study were used to create Bayesian networks to determine the effect of firm size on intra-family succession.

\subsection{Bayesian networks}

Bayesian networks are annotated directed acyclic graphs that encode probabilistic relationships among nodes of interest in an uncertain reasoning problem (Pai et al., 2003). The representation describes these probabilistic relationships and includes a qualitative structure that facilitates communication between a user and a system incorporating a probabilistic model. Bayesian networks are based on the work of the mathematician and theologian Rev. Thomas Bayes who worked with conditional probability theory in the late 1700 s to discover a basic law of probability which came to be known as Bayes' theorem. Bayes' theorem states that:

$$
\mathrm{P}(\mathrm{H} \mid \mathrm{E}, \mathrm{c})=\frac{\mathrm{P}(\mathrm{H} \mid \mathrm{c}) \times \mathrm{P}(\mathrm{E} \mid \mathrm{H}, \mathrm{c})}{\mathrm{P}(\mathrm{E} \mid \mathrm{c})}
$$

The posterior probability is given by the left-hand term of the equation $[\mathrm{P}(\mathrm{H} \mid \mathrm{E}, \mathrm{c})]$. It represents the probability of hypothesis $\mathrm{H}$ after considering the effect of evidence $\mathrm{E}$ on past experience $\mathrm{c}$. The term $\mathrm{P}(\mathrm{H} \mid \mathrm{c})$ is the a-priori probability of $\mathrm{H}$ given $\mathrm{c}$ alone. Thus, the a-priori probability can be viewed as the subjective belief of occurrence of hypothesis $\mathrm{H}$ based upon past experience. The likelihood, represented by the term $\mathrm{P}(\mathrm{E} \mid \mathrm{H}, \mathrm{c})$, gives the probability of the evidence assuming the hypothesis $\mathrm{H}$ and the background information $\mathrm{c}$ is true. The term $\mathrm{P}(\mathrm{E} \mid \mathrm{c})$ is independent of $\mathrm{H}$ and is regarded as a normalising or scaling factor (Niedermayer, 2003). Thus, Bayesian networks provide a methodology for combining subjective beliefs with available evidence.

Bayesian networks represent a special class of graphical models that may be used to depict causal dependencies between random variables (Cowell et al., 2007). Graphical models use a combination of probability theory and graph theory in the statistical modelling of complex interactions between such variables. Bayesian networks have evolved as a useful tool in analysing uncertainty. When Bayesian networks were first introduced, assigning the full probability distributions manually was time intensive. Solving a Bayesian network with a considerable number of nodes is known to be a nondeterministic polynomial time hard [NP hard] problem (Dagum and Luby, 1993). However, significant advancements in computational capability along with the 
development of heuristic search techniques to find events with the highest probability have enhanced the development and understanding of Bayesian networks. Correspondingly, the Bayesian computational concept has become an emergent tool for a wide range of risk management applications (Cowell et al., 2007). The methodology has been shown to be especially useful when information about past and/or current situations is vague, incomplete, conflicting, and uncertain.

\section{Results}

Demographic information on the survey participants in the Lockamy et al. (2016) study is provided in Table 3. This information was used to segment the survey responses by firm size based upon number of employees into the following categories:

1 less than 50 employees

$250-100$ employees

3 greater than 100 employees.

Table 3 Demographic information of survey participants

\begin{tabular}{|c|c|c|c|c|c|c|c|}
\hline \multicolumn{8}{|c|}{ Business type } \\
\hline Service & Retail & Manufacturing & Construction & Vholesale & Not & or-profit & Other \\
\hline 21 & 20 & 6 & 6 & 2 & & 1 & 12 \\
\hline \multicolumn{8}{|c|}{ Legal form of business } \\
\hline $\begin{array}{l}\text { Private } \\
\text { corporation }\end{array}$ & $L L C$ & Partnership & \multicolumn{2}{|l|}{$\begin{array}{c}\text { Sole } \\
\text { proprietorship }\end{array}$} & Trust & \multicolumn{2}{|c|}{ Other } \\
\hline 37 & 17 & 6 & \multicolumn{2}{|l|}{1} & 1 & \multicolumn{2}{|c|}{6} \\
\hline \multicolumn{8}{|c|}{ Geographic distribution of sales } \\
\hline Local & Regional & Statewide & National & \multicolumn{2}{|c|}{ Global } & \multicolumn{2}{|c|}{ North America } \\
\hline 21 & 16 & 11 & 8 & & 7 & \multicolumn{2}{|c|}{5} \\
\hline \multicolumn{8}{|c|}{ Number of business locations } \\
\hline One & \multicolumn{2}{|r|}{ Two } & \multicolumn{2}{|l|}{ Three } & \multicolumn{3}{|c|}{ Four } \\
\hline 43 & \multicolumn{2}{|r|}{19} & \multicolumn{2}{|l|}{5} & \multicolumn{3}{|c|}{1} \\
\hline \multicolumn{8}{|c|}{ Number of employees } \\
\hline Less than 50 & \multicolumn{2}{|r|}{50 to 100} & \multicolumn{5}{|c|}{ Greater than 100} \\
\hline 52 & \multicolumn{2}{|r|}{10} & \multicolumn{5}{|c|}{6} \\
\hline \multicolumn{8}{|c|}{ Percentage of family ownership } \\
\hline Less than $50 \%$ & \multicolumn{2}{|r|}{ Exactly $50 \%$} & & & ater $t$ & an $50 \%$ & \\
\hline 57 & & 5 & & & & & \\
\hline & Nun & mber of successio & ons since company' & 's foundir & & & \\
\hline One & Two & Three & Four & & ive & & Six \\
\hline 39 & 12 & 5 & 8 & & 2 & & 2 \\
\hline
\end{tabular}


An a-priori probability table was constructed for each firm size category from the survey data based on the mean percentages tabulated for the key determinants preventing intra-family succession, presented in Table 4. The table reveals that individual/relationship factors have the highest probability of inhibiting succession, followed by governance, context, and process factors. Bayesian networks were constructed using the a-priori probabilities in Table 4. The network for firms containing less than 50 employees is presented in Figure 1. The factors in the Bayesian network are represented by nodes. Each node contains states, or a set of probable values for each factor. The factors in the network illustrated in Figure 1 can exist at two states (yes or no). Nodes are connected to show causality with an arrow (known as an edge) indicating the direction of influence. When two nodes are joined by an edge, the causal node is referred to as the parent of the influenced (child) node. Child nodes are conditionally dependent upon their parent nodes. Thus, in Figure 1, the probability of one of the three events occurring which prevent intra-family succession, as theorised by De Massis et al. (2008) and empirically tested by Lockamy et al. (2016), is dependent on the a priori probabilities associated with context, individual/relationship, process, and governance factors. These probabilities are illustrated in the network nodes. Figure 1 shows that there is a $46 \%$ probability of intra-family succession not occurring in firms containing less than 50 employees based upon the a-priori probabilities associated with the key determinants.

Figure 1 Bayesian belief network

Firm size $=$ less than 50 employees

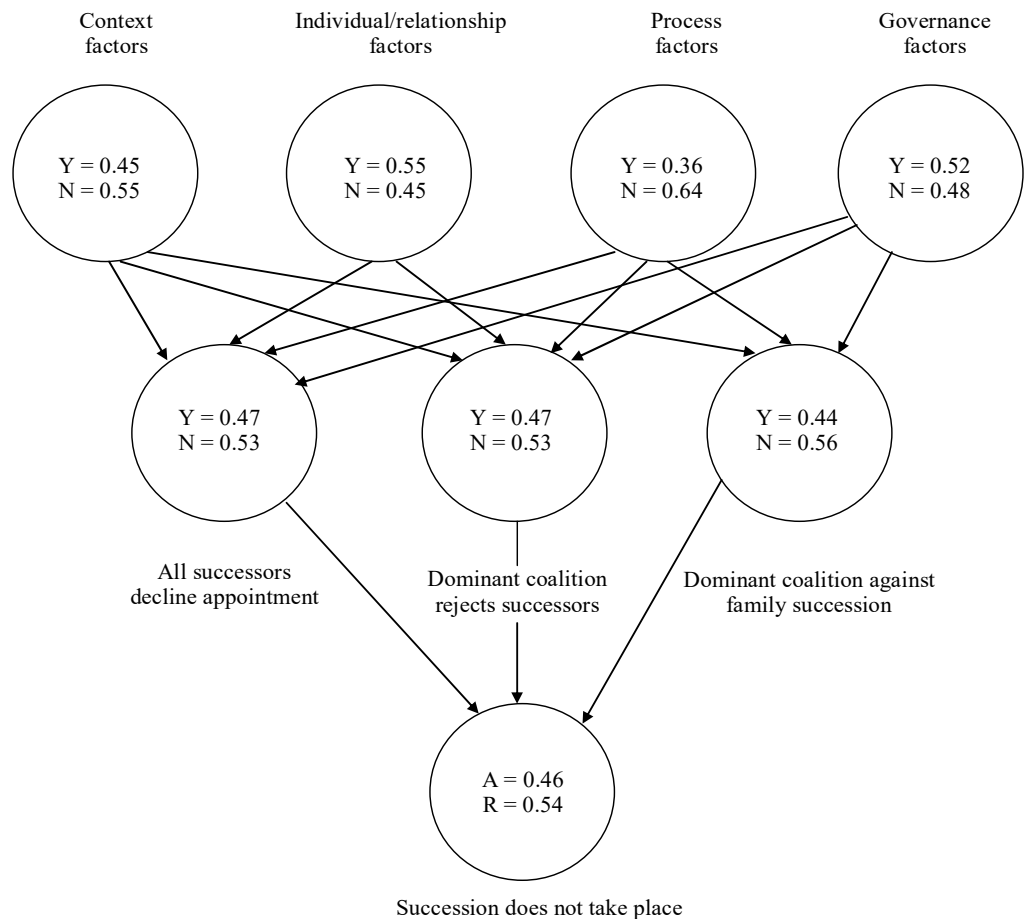

Notes: $\mathrm{Y}=$ probability of preventing intra-family succession,

$\mathrm{N}=$ probability of not preventing intra-family succession,

$\mathrm{A}=$ probability succession does not take place,

$\mathrm{R}=$ probability succession does take place. 
Table 4 A-priori probabilities for key determinants affecting intra-family succession segmented by firm size

\begin{tabular}{lcc}
\hline Firm size & Construct & A-priori probability \\
\hline Less than 50 employees & Context factors & 0.45 \\
& Individual/relationship factors & 0.55 \\
& Process factors & 0.36 \\
& Governance factors & 0.52 \\
$50-100$ employees & Context factors & 0.43 \\
& Individual/relationship factors & 0.54 \\
& Process factors & 0.34 \\
Greater than 100 employees & Governance factors & 0.52 \\
& Context factors & 0.42 \\
& Individual/relationship factors & 0.54 \\
& Process factors & 0.34 \\
& Governance factors & 0.47 \\
\hline
\end{tabular}

Table 5 Effect of firm size on intra-family succession

\begin{tabular}{lc}
\hline Firm size & Probability of no intra-family succession \\
\hline Less than 50 employees & 0.46 \\
$50-100$ employees & 0.45 \\
Greater than 100 employees & 0.43 \\
\hline
\end{tabular}

The effect of firm size on intra-family succession was evaluated by constructing Bayesian networks using the a-priori probabilities for each firm size category illustrated in Table 4. The results of analysis are provided in Table 5. An examination of Table 5 reveals that there is a $46 \%$ probability of intra-family succession not occurring in firms containing less than 50 employees based upon the a priori probabilities associated with the key determinants, as stated earlier. The table also shows that there is a $43 \%$ probability that intra-family succession does not take place in firms containing more than 100 employees. Finally, the results in Table 5 show that there is a $45 \%$ probability that intra-family succession does not take place in firms containing 50 to 100 employees. These results examined collectively suggest that there is a higher probability that intra-family succession does not take place in a smaller firm than in a larger organisation.

\section{Managerial actions}

The results of this study suggest several managerial actions that can be taken to improve the probability of intra-family business succession in smaller firms:

1 avoid the use of a family-comprised BOD where the incumbent is both the Chief Executive Officer and Chairman of the BOD

2 develop a formalised process for successor selection which contains rationale and objective criteria 
3 ensure that all potential successors have work experience in the family business

4 ensure that all potential successors develop relationships with major customers and suppliers

5 amass the necessary level of financial resources to support successful succession.

The Lockamy et al. (2016) study concluded that process factors have the largest effect on increasing the probability that intra-family succession does not take place, followed by context and governance factors. Conversely, the study concluded that individual/relationship factors have the smallest effect on increasing the probability of no intra-family succession. These factors also had the smallest effect on decreasing the probability that intra-family succession does not take place in their study. Finally, the study also concluded that governance factors have the largest effect on decreasing the probability that intra-family succession does not take place. Since governance factors have the largest effect on decreasing the probability of no intra-family succession, it is imperative that the first managerial action is followed to improve the chances of succession. Managerial actions two, three, and four address process factors which have the largest effect on increasing the probability that intra-family succession does not take place. A lack of a formalised selection process can significantly impede intra-family succession. Moreover, a potential successor with no work experience in the family business or lacks relationships with major customers and suppliers can be problematic with respect to intra-family business succession. Finally, context factors were found to have the second largest effect on increasing the probability that intra-family succession does not take place. A key determinant categorised as a context factor is the financial health of the organisation. Thus, it is critical that organisations that are preparing for intra-family succession set aside the appropriate level of financial resources to sustain potential tax burdens related to succession, and to liquidate the possible exit of heirs from the family business.

Although individual/relationship factors were found to be key determinants in preventing intra-family succession in family businesses, they have the smallest effect on either increasing or decreasing the probability of no intra-family succession. However, these organisations should try to minimise sibling rivalries, conflicts between successors and non-family members, and other detrimental individual/relationship factors which could inhibit successful intra-family succession. The level of commitment and motivation displayed by the potential successors are key determinants which should be closely monitored to improve the likelihood of successful intra-family succession.

The managerial actions prescribed above are essential for successful intra-family succession in all firms. However, the need for these actions is magnified in smaller firms due to the immediate and profound impact that poor decisions in the areas of relationships, processes, governance, and finances can have on a small organisation.

\section{Conclusions}

The results of this study indicate that firm size can affect intra-family succession in family businesses. Through the use of Bayesian network analysis, it is shown that there is a $46 \%$ probability of intra-family succession not occurring in firms containing less than 50 employees based upon the a priori probabilities associated with the key determinants 
provided by the study participants. Conversely, the results indicate a $43 \%$ probability that intra-family succession does not take place in firms containing more than 100 employees. Thus, the results of this study can be used by researchers as a basis for conducting additional empirical studies in this area. In addition, the managerial actions prescribed in the study can also be used by practitioners to assist them in conducting intra-family business successions.

\section{Limitations}

There are several limitations associated with this study. First, although a $27.2 \%$ response rate obtained in the Lockamy et al. (2016) study is acceptable, the survey respondents may not represent the entire cross-section of family-owned business in the United States. Second, the subgroup sample sizes were small, ranging from $n=6$ to $n=52$. Thus, the subgroups may not be representative of all family businesses in a particular category. Finally, the selection of the key determinants in the Lockamy et al. (2016) study was made based upon the highest value extracted from the principle components analysis. Combining these variables with other relatively high values may lead to different results.

\section{Future research}

Empirical studies which examine the key determinants preventing intra-family business succession should be conducted to determine if these determinants are influenced by other demographic factors. Future researchers should continue to explore the use of Bayesian networks to assess how family businesses can improve the likelihood of successful intra-family business succession. Finally, the effect of an individual variable on preventing intra-family business succession within a construct should be examined by future researchers.

\section{References}

Adendorff, C. and Halkias, D. (2014) 'Leveraging ethnic entrepreneurship, culture and family dynamics to enhance good governance and sustainability in the immigrant family business', Journal of Developmental Entrepreneurship, Vol. 19, No. 2, pp.1-23.

Allenby, G., Bakken, D. and Rossi, P. (2004) 'The HB revolution: how Bayesian methods have changed the face of marketing research', Marketing Research, Vol. 16, No. 2, pp.20-25.

Andraszewicz, S., Scheibehenne, B., Rieskamp, J., Grasman, R., Verhagen, J. and Wagenmakers, E-J. (2015) 'An introduction to Bayesian hypothesis testing for management research', Journal of Management, Vol. 41, No. 2, pp.521-543.

Barach, J.A. and Gantisky, J.B. (1995) 'Successful succession in family business', Family Business Review, Vol. 8, No. 2, pp.131-155.

Barach, J.A., Gantisky, J., Carson J.A. and Doochin, B.A. (1988) 'Entry of the next generation: strategic challenge for family business', Journal of Small Business Management, Vol. 26, No. 2, pp.49-56.

Basco, R. and Rodríguez, M. (2009) 'Studying the family enterprise holistically: evidence for integrated family and business systems', Family Business Review, Vol. 22, No. 1, pp.1-22. 
Berent-Braun, M.M. and Uhlaner, L.M. (2012) 'Family governance practices and teambuilding: paradox of the enterprising family', Small Business Economics, Vol. 38, No. 4, pp.103-111.

Block, J., Miller, D. and Wagner, D. (2014) 'Bayesian methods in family business research', Journal of Family Business Strategy, Vol. 5, No. 1, pp.97-104.

Brenes, E.R., Madrigal, K. and Requena, B. (2011) 'Corporate governance and family business performance', Journal of Business Research, Vol. 64, No. 3, pp.280-285.

Brockhaus, R.H. (2004) 'Family business succession: suggestions for future research', Family Business Review, Vol. 17, No. 2, pp.165-177.

Bruce, D. and Picard, D. (2006) 'Making succession a success: perspectives from Canadian small and medium-sized enterprises', Journal of Small Business Management, Vol. 44, No. 2, pp.306-309.

Bruce, D. and Picard, D. (2006) 'Making succession a success: perspectives from Canadian small and medium-sized enterprises', Journal of Small Business Management, Vol. 44, No. 2, pp.306-309.

Chrisman, J.J., Chua, J.H. and Sharma, P. (1998) 'Important attributes of successors in family businesses: an exploratory study', Family Business Review, Vol. 11, No. 1, pp.19-34.

Chua, J.H., Chrisman, J.J. and Sharma, P. (2003) 'Succession and nonsuccession concerns of family firms and agency relationship with nonfamily managers', Family Business Review, Vol. 16, pp.89-107.

Churchill, N.C. and Hatten, K.J. (1987) 'Non-market based transfers of wealth and power: a research framework for small businesses', American Journal of Small Business, Vol. 11, No. 3, pp.51-64.

Combs, J.G., Penney, C.R., Crook, T.R. and Short, J.C. (2010) 'The impact of family representation on CEO compensation', Entrepreneurship: Theory \& Practice, Vol. 34, No. 6, pp.125-1144.

Cowell, R.G., Verrall, R.J. and Yoon, Y.K. (2007) 'Modeling operational risk with Bayesian networks', Journal of Risk and Insurance, Vol. 74, No. 4, pp.795-827.

Dagum, P. and Luby, M. (1993) 'Approximating probabilistic inference in Bayesian belief networks is NP-hard', Artificial Intelligence, Vol. 60, No. 1, pp.141-153.

Davis, P.S. (1983) 'Realizing the potential of the family business', Organizational Dynamics, Vol. 2, No. 1, pp.47-56.

Davis, P.S. and Harveston, P.D. (1998) 'The influence of family on business succession process: a multigenerational perspective', Entrepreneurship Theory and Practice, Vol. 22, No. 3, pp.31-53.

De Massis, A., Chua, J.H. and Chrisman, J.J. (2008) 'Factors preventing intra-family succession', Family Business Review, Vol. 21, No. 2, pp.183-199.

Dean, M., Shook, C. and Payne, G. (2007) 'The past, present, and future of entrepreneurship research: data analytic trends and training', Entrepreneurship: Theory and Practice, Vol. 31, No. 4, pp. 601-618.

Dick, R. and Kets de Vries, M.F.R. (1992) The Bonnier Group in Transition, Case Study, INSEAD Case Publishing, Fontainebleau.

Dyer Jr., W.J. (1986) Cultural Change in Family Business: Anticipating and Managing Business and Family Transitions, Jossey-Bass, San Francisco, CA.

Eisenhardt, K.M. (1989) 'Agency theory: an assessment and review', Academy Management Review, Vol. 14, No. 1, pp.532-550.

Fahed-Sreih, J. (2009) 'An exploratory study on a new corporate governance mechanism: evidence from small family firms', Management Research News, Vol. 32, No. 1, pp.50-61.

Gedajlovic, E., Carney, M., Chrisman, J. and Kellermanns, F. (2012) 'The adolescence of family firm research: taking stock and planning for the future', Journal of Management, Vol. 38, No. 4, pp.1010-1037. 
Handler, W.C. (1990) 'Succession in family firms: a mutual role adjustment between entrepreneur and next-generation family members', Entrepreneurship Theory and Practice, Vol. 15, No. 1, pp.37-51.

Handler, W.C. (1992) 'Succession experience of the next generation', Family Business Review, Vol. 5, No. 3, pp.283-307.

Handler, W.C. and Kram, K.E. (1988) 'Succession in family firms: the problem of resistance', Family Business Review, Vol. 1, No. 4, pp.361-381.

Hansen, M., Perry, L. and Reese, C. (2004) 'A Bayesian operationalization of the resource-based view', Strategic Management Journal, Vol. 25, No. 13, pp.1279-1295.

Kelly, L.M., Athanassiou, N. and Crittenden, W.F. (2000) 'Founder centrality and strategic behavior in the family-owned firm', Entrepreneurship Theory and Practice, Vol. 25, No. 2, pp.27-42.

Kepner, E. (1983) 'The family and the firm: a co-evolutionary perspective', Organizational Dynamics, Vol. 12, No. 1, pp.57-70.

Kets de Vries, M.F.R. (1986) Roland and Stone Inc., Case Study, INSEAD Case Publishing, Fontainebleau.

Kets de Vries, M.F.R. (1989) The Nadia Corporation, Case Study, INSEAD Case Publishing, Fontainebleau.

Kim, W. and Mauborgne, R. (1993) 'Procedural justice, attitudes, and subsidiary top management compliance with multinational's corporate strategic decisions', Academy of Management Journal, Vol. 36, No. 3, pp.502-526.

Kruschke, J., Aguinis, H. and Joo, H. (2012) 'The time has come: Bayesian methods for data analysis in the organizational sciences', Organizational Research Methods, Vol. 15, No. 4, pp.722-752.

Kuan, T.H., Li, C.S. and Chu, S.H. (2011) 'Cash holdings and corporate governance in family controlled firms', Journal of Business Research, Vol. 64, No. 7, pp.757-764.

Lansberg, I. (1983) 'Managing human resources in family firms: the problem of institutional overlap', Organizational Dynamics, Vol. 12, No. 1, pp.39-46.

Lansberg, I. (1988) 'The succession conspiracy', Family Business Review, Vol. 1, No. 2, pp.119-143.

Levinson, H. (1971) 'Conflicts that plague family businesses', Harvard Business Review, Vol. 49, No. 2, pp.90-98.

Lockamy, A., Carson, C.M. and Lohrke, F.T. (2016) 'An evaluation of key determinants preventing intra-family business succession', Journal of Family Business Management, Vol. 6, No. 1, pp.64-80.

McCollom, M.E. (1988) 'Integration in the family firm: when the family system replaces controls and culture', Family Business Review, Vol. 2, No. 1, pp.399-417.

Molly, V., Leveren, E. and Deloof, M. (2010) 'Family business succession and its impact on financial structure and performance', Family Business Review, Vol. 23, No. 2, pp.131-147.

Montemerlo, D. (2000) Il governo delle imprese familiari. Modelli e strumenti per gestire $i$ rapporti traproprietà e impresa, EGEA, Milano.

Morris, M.H., Williams, R.W., Allen J.A. and Avila R.A. (1997) 'Correlates of success in family business transitions', Journal of Business Venturing, Vol. 12, No. 5, pp.385-401.

Niedermayer, D. (2003) An Introduction to Bayesian Networks and their Contemporary Applications [online] http://www.niedermayer.ca/papers/bayesian (accessed 26 July 2013).

Pai, R., Kallepalli, V., Caudill, R. and Zhou, M. (2003) 'Methods toward supply chain risk analysis', IEEE International Conference on Systems, Man and Cybernetics, Vol. 5, No. 1, pp.4560-4565.

Parrini, L. (1998) 'Finanza per las succession nelle PMI. Private equity e impreses familiari', Economia \& Management, Vol. 2, No. 1, pp.57-67. 
Parrini, L. (2000) 'La finanza straordinaria per pianificare la successione', Amministrazione \& Finanza, Vol. 14, No. 1, pp.63-66.

Rosenblatt, P.C., de Mik, L., Anderson, R.M. and Johnson, P.A. (1985) 'The Family in Business: Understanding and Dealing with the Challenges Entrepreneurial Families Face, Jossey-Bass, San Francisco, CA.

Sharma, P. and Rao, S. (2000) 'Successor attributes in Indian and Canadian family firms: a comparative study', Family Business Review, Vol. 13, No. 4, pp.313-330.

Sharma, P., Chrisman, J.J., Pablo, A.L. and Chua, J.H. (2001) 'Determinants of initial satisfaction with the succession process in family firms: a conceptual model', Entrepreneurship Theory and Practice, Vol. 25, No. 3, pp.17-35.

Siebels, J.F. and zu Knyphausen-Aufseß, D. (2012) 'A review of theory in family business research: the implications for corporate governance', International Journal of Management Reviews, Vol. 14, No. 3, pp.280-304.

Sonnenfeld, J. (1988) The Hero's Farewell: What Happens when CEOs Retire, Oxford University Press, New York.

Stavrou, E. (1999) 'Succession in family businesses: exploring the effects of demographic factors on offspring intentions to join and take over the business', Journal of Small Business Management, Vol. 37, No. 3, pp.43-62.

Upton, N., Vinton, K., Seaman, S. and Moore, C. (1993) 'Research note: family business consultants - who we are, what we do, and how we do it?', Family Business Review, Vol. 6, No. 1, pp.301-311.

Ward, J.L. (1987) Keeping the Family Business Healthy: How to Plan for Continuing Growth, Profitability and Family Leadership, Jossey-Bass, San Francisco, CA.

Ward, J.L. (1997) Keeping the Family Business Healthy: How to Plan for Continuity Growth, Profitability and Family Leadership, Business Owner Resources, Marietta, GA.

Ward, J.L. (2004) Perpetuating the Family Business. 50 Lessons Learned from Long-Lasting, Successful Families in Business, Palgrave Macmillan, New York.

Yu, A., Lumpkin, G.T., Sorenson, R.L. and Brigham, K.H. (2012) 'The landscape of family business outcomes: a summary and numerical taxonomy of dependent variables', Family Business Review, Vol. 25, No. 1, pp.33-57.

Zyphur, M. and Oswald, F. (2013) 'Bayesian estimation and inference: a user's guide', Journal of Management, Vol. 41, No. 1, pp.390-420. 